\title{
Establishment of Tuberculous Antigen-Specific T Cell Line and its Effect on Hepatic Granuloma Formation in BCG-Infected Nude Mice
}

\author{
Shigeki YAMAMOTO, Hiroshi IWAI, and Katsumoto UEDA \\ Department of Veterinary Public Health, The Institute of Public Health, 4-6-1 Shiroganedai, Minato-ku, Tokyo 108, \\ Japan
}

(Received 18 September 1987/Accepted 26 October 1987)

\begin{abstract}
We established tuberculin-active peptide (TAP)-reactive $\mathrm{T}$ cell line, by repeating cycles of antigen-stimulation and resting culture, from the popliteal lymph node of BALB/cA nu/ + mice immunized with Freund's complete adjuvant containing Mycobacterium tuberculosis strain Aoyama B. Surface phenotype of anti-TAP and anti-SV T cell lines was determined as Thy $1.2^{+}, \mathrm{Lyt} 1.2^{+}, \mathrm{L} 3 \mathrm{~T} 4^{+}$, and Lyt $2^{-}$by flow cytometry. They produced IL-2 assessed by $\left[{ }^{3} \mathrm{H}\right]$-thymidine incorporation of CTLL-2, and also produced MIF assessed by the indirect capillary tube method. T cell lines exhibited the delayed-type footpad response by a local passive transfer. Anti-TAP T cell line could produce hepatic granulomas 2 weeks after adoptive transfer via the tail or the portal vein to BCG-infected nude mice, but recipients of anti-SV T cell line and controls without cell transfer did not. From the observation of the tissue section of these mice, granulomas were also produced in the splenic white pulps of mice which developed hepatic granulomas. This findings suggested that a portion of transferred lined $\mathrm{T}$ cells had homed and functioned in the lymphoid tissues. KEY wORDs: granuloma formation, nude mouse, $\mathrm{T}$ cell line, tuberculosis.
\end{abstract}

The infectious granuloma is a characteristic lesion of tuberculosis, and various other mycobacterioses of domestic animals as well as humans, and it is generally considered that antibacterial resistance of the host emerges in the lesion $[3,4]$. However, the mechanism of the development of lesion and underlying immunological processes have not yet been clarified.

Using nude (nu/nu) mice, we have established a model to elucidate the role of $T$ cells involved in granuloma formation. $\mathrm{Nu} / \mathrm{nu}$ mice infected intravenously (i.v.) with Mycobacterium bovis BCG developed granulomas poorly, but a transfer of syngeneic T cells produced many in their liver $[19,20]$. However, we have encountered difficulties in investigating the subsets of $\mathrm{T}$ cells required for granuloma formation, because the transferred $\mathrm{T}$ cells were not single cell population, and also because of the difficulty to distinguish the adoptive immunity from the active immunity in this model system. In order to avoid these difficulties in observing adoptive immunity, we attempted to establish a tuberculous antigen-reactive $T$ cell line from the popliteal lymph nodes of euthymic nu/ + mice which were immunized with Mycobacterium tuberculosis in the form of Freund-type oil emulsion (FCA), and investigated in vitro and in vivo activities of the $\mathrm{T}$ cell line.

\section{MATERIALS AND METHODS}

Mice: Both sexes of nu/nu or nu/ + mice of BALB/cA background were used at 4 to 12 weeks of age. These mice were bred in our laboratory and maintained under barriersustained condition on pellet F2 (Funabashi Farm Co., Chiba, Japan) and acidified tap water ad libitum.

Bacteria: Mycobacterium bovis BCG Japanese strain was subcultured in Dubos' 
liquid medium as described previously [18]; $3 \times 10^{6}$ viable $B C G$ were inoculated intravenously (i.v.) via the tail vein into nu/nu mice.

Immunization of mice: Heat-killed $\mathrm{Myco}$ bacterium tuberculosis strain Aoyama B $(500 \mu \mathrm{g} / \mathrm{m} l)$ in FCA was injected $(0.05 \mathrm{~m} l)$ subcutaneously into the both hind footpads of $\mathrm{nu} /+$ mice. For anti-Sendai virus (SV)-T cell line, $\mathrm{nu} /+$ mice were infected intranasally with SV $\left(\mathrm{MN}\right.$ strain, $8 \times 10^{2} \mathrm{TCID}_{50} / 25$ $\mu l)$.

Antigens: $\mathrm{BCG}$ organisms were cultured on Sauton's synthetic medium for 8 weeks at $37^{\circ} \mathrm{C}$ and were killed by heating at $100^{\circ} \mathrm{C}$ for 30 min. After filtration, BCG was washed with ethyl alcohol-acetone and dried in a vacuum. Dried BCG was defatted by repeated extraction with ether: ethyl alcohol (1:1), chloroform, and chloroform: methanol $(2: 1)$, as described by Azuma, et al. [1]. Defatted BCG was dried and suspended 1 $\mathrm{mg} / \mathrm{m} l$ in phosphate buffered saline $(\mathrm{pH} 7.2$, $\operatorname{PBS}(-))$, and then autoclaved at $121^{\circ} \mathrm{C}$ for 15 min. Tuberculin-active peptide (TAP) [21] and purified protein derivatives (PPD) were prepared from $M$. tuberculosis strain Aoyama B. Ovalbumin (grade V, OVA) was obtained from Sigma Chem. Co. (St. Louis, MO, U. S. A.) Ultravioletinactivated Sendai virus MN strain (UV-SV) was prepared as follows; $2 \mathrm{~m} l$ of virus suspension (about $5000 \mathrm{HA}$ units $/ 25 \mu l$ ) was irradiated in a 9-cm-diameter plastic dish for $10 \mathrm{~min}$ at a distance of $10 \mathrm{~cm}$ from a 15 -watt UV-light under constant stirring.

Viability of the cells: Viability of the cells was determined by the trypan blue dye exclusion test.

$T$ cell growth factor (TCGF): Spleen cells $\left(5 \times 10^{6}\right)$ of Sprague Dawley rat were cultured with $5 \mu \mathrm{g} / \mathrm{m} l$ concanavalin A (Sigma Chem. Co., St. Louis, MO., U. S. A.) in RPMI-1640 medium (Gibco Lab., Grand Island Biol. Co., Grand Island, NY., U. S. A.) supplemented with $2 \mathrm{mg} / \mathrm{m} l$ L- glutamine, $5 \times 10^{-5} \mathrm{~mol} / \mathrm{ml}$ 2-mercaptoethanol, $20 \mu \mathrm{g} / \mathrm{ml}$ gentamicin (complete medium, CM) and 5\% fetal calf serum (FCS, General Scientific Lab., Los Angeles, CA, U. S. A.) at $37^{\circ} \mathrm{C}$ under $5 \% \mathrm{CO}_{2}$ in air. Twenty-four hours later, culture supernatants were collected and centrifuged $13300 \mathrm{~g}$ for $30 \mathrm{~min}$, and then methyl-alfa-Dmannopyranoside (Sigma Chem. Co., St. Louis, MO, U. S. A.) was added at 40 $\mathrm{mg} / \mathrm{m} l$ to the supernatant, filtered with $0.2-\mu \mathrm{m}$-pore membrane filter (Toyoroshi, Inc., Tokyo, Japan), and stored at $-20^{\circ} \mathrm{C}$ until use.

Monoclonal antibodies (Mab) and staining method of cell surface antigens: Fluorescein isothiocyanate (FITC) conjugated antiThy1.2 Mab (Bio Makor, Israel, 1:200), anti Lyt1.2 Mab (Cederlane Lab., Ltd., Ontario, Canada, 1:500), biotin-labelled anti-Lyt2 Mab (Becton Dickinson Immunocytometry Systems, Mountain View, CA, U. S. A., 1:200), anti-L3T4 Mab (Becton Dickinson Immunocytometry Systems, Mountain View, CA, U. S. A., 1:250), FITC conjugated Rabbit IgG.F(ab') ${ }_{2}$ anti-mouse IgG (Cappel Lab., Inc., Cochranville, PA, U. S. A., 1:20), FITC-conjugated goat $\mathrm{IgG} \cdot \mathrm{F}\left(\mathrm{ab}^{\prime}\right)_{2}$ anti-rat IgG (Cappel, Lab., Inc., Cochranville, PA, U. S. A., 1:20), avidin-FITC (Vector Lab., Inc., CA, U. S. A., 1:1000) were used at the indicated final dilutions in PBS (-). Lined $\mathrm{T}$ cells were suspended at $10^{6} / \mathrm{m} l$ in $5 \%$ FCS PBS (-) containing $0.1 \% \mathrm{NaN}_{3}$ and stained with respective $\mathrm{Mab}$ for $30 \mathrm{~min}$ on ice. T cells responding to anti-Lyt1.2, anti-Lyt2, and anti-L3T4 Mab were stained with FITCconjugated secondary Mab or avidin-FITC (in the latter case, no addition of FCS in PBS (-)) for 30 min on ice. And then cells were washed 3 times with PBS $(-)$, and resuspended at a dose of $2 \times 10^{6} / \mathrm{m} l$ for analysis of flow cytometry (Spectram III, Ortho Diagnostics systems, NJ, U. S. A.). Assay of IL-2 production: Lined T cells 
$\left(10^{4} /\right.$ well) were cultured with $25 \mu \mathrm{g} / \mathrm{ml} \mathrm{TAP}$ and 2000-rad irradiated syngeneic spleen cells (antigen presenting cells, APC, red blood cells were lysed with $0.83 \% \mathrm{NH}_{4} \mathrm{Cl}$ ) in $0.2 \mathrm{ml} 10 \%$ FCS-CM in a 96-well culture plate (Costar, \#3599, MA, U. S. A.) at $37^{\circ} \mathrm{C}$ in $\mathrm{CO}_{2}$ incubator. As controls, $\mathrm{T}$ cell line and $\mathrm{APC}$ without antigen, or $\mathrm{T}$ cell line with or without antigen were cultured for 24 hr under the same condition. Culture supernatants'were collected and assayed on CTLL-2 as described previously [10]. Briefly, IL-2-dependent cell line CTLL-2 (10 $4 / 0.1$ $\mathrm{m} l /$ well) was cultured with serial dilution of culture supernatant $(0.1 \mathrm{~m} / /$ well $)$ in a 96 well flatbottom microculture plate (Costar, \#3599, MA, U. S. A.) for $48 \mathrm{hr}$ at $37^{\circ} \mathrm{C}$ under $5 \% \mathrm{CO}_{2}$ in air. Then $0.25 \mu \mathrm{Ci}$ $\left[{ }^{3} \mathrm{H}\right]$-thymidine (TdR) (TRK61, Amersham Japan Ltd., Japan) was added for the final $18 \mathrm{hr}$ of culture. Cells were harvested on filter paper with a cell harvester (Flow Lab., U. K.) and counted with a liquid scintillation counter (LSC-601, Aloka Inc., Tokyo, Japan).

Assay of MIF: $10^{6}$ lined $\mathrm{T}$ cells were cultured with $5 \times 10^{6}$ APC under presence or absence of antigen in $2 \mathrm{~m} l$ of $10 \%$ FCS-CM. Twenty-four hours later, culture supernatants were collected and sterilized with $0.22-\mu \mathrm{m}$-millipore filter and stored at $-70^{\circ} \mathrm{C}$ until use. Peritoneal exudate cells were harvested and pooled from 5 to $6 \mathrm{nu} / \mathrm{nu}$ mice which had been injected i.p. 4 days before with $2 \mathrm{~m} l$ of $3 \%$ thioglycolate (NIH: Difco Lab., MI, U. S. A.), by injecting $3 \mathrm{ml}$ of 5\% FCS-MEM containing 10 units heparin (Novo, Industry A/S, Bagsvaer, Denmark). After 2 washings with 5\% FCS-MEM, these cell suspensions were packed into capillary tubes $(0.75 \mathrm{~mm}$ inner diameter $)$ and centrifuged $100 \mathrm{~g}$ for $3 \mathrm{~min}$. The cell-packed portion of the capillary tubes was cut out and placed in a 24-well Costar Plate, 2 tubes per well, and incubated with $10 \%$ FCS-CM containing $50 \%$ or $25 \%$ culture supernatant for $24 \mathrm{hr}$ at $37^{\circ} \mathrm{C}$ in $\mathrm{CO}_{2}$ incubator. The longitudinal and lateral diameters of the migration area were measured under a micrometer, and percent migration inhibition was calculated as follows:

$100-\frac{\text { Migration area with antigen }}{\text { Migration area without antigen }} \times 100$

Antigen specific proliferation of $T$ cell line: $10^{4}$ lined T cells were cultured with $5 \times 10^{5}$ $\mathrm{APC}$ with various antigens in $10 \% \mathrm{FCS}-\mathrm{CM}$ at $37^{\circ} \mathrm{C}$ in $\mathrm{CO}_{2}$ incubator and $\left[{ }^{3} \mathrm{H}\right]-\mathrm{TdR}$ incorporation was examined on the final 18 hr of 4-day culture.

Local passive transfer of delayed-type hypersensitivity $(D T H): 5 \times 10^{5}$ lined T cells and $20 \mu \mathrm{g}$ heat-killed and defatted BCG in $0.04 \mathrm{ml}$ of CM was injected intradermally to a left hind footpad of nu/ + mice. Footpad swelling was measured with a dial gauge caliper (Schnell tastar, System Kröplin, West Germany) at 3, 24, and 72 hr later. Transfer of DTH by anti-SV T cell line was carried out according to the method described by Ertl [9]. Briefly, UV-SV (4000 $\mathrm{HA}$ ) in $0.02 \mathrm{ml}$ of $\mathrm{CM}$ were injected into a left hind footpad of $\mathrm{nu} /+$ mice. Four hours later, $5 \times 10^{5}$ lined $\mathrm{T}$ cells in $0.02 \mathrm{ml}$ of $\mathrm{CM}$ were injected into the same footpad. Footpad swelling was measured $24 \mathrm{hr}$ later. Injection of $\mathrm{T}$ cell only or antigen only were used as controls.

Injection of lined $T$ cells and method of counting hepatic granulomas: $3 \times 10^{6} \mathrm{BCG}$ were inoculated i.v. into nu/nu mice. Twenty-four hours later, the nu/nu mice were injected with lined T cells via the tail vein or the portal vein. In the case of injection via the portal vein, mice were anesthetized with an intraperitoneal injection of $50 \mathrm{mg} / \mathrm{kg}$ sodium pentobarbital, the abdomen was dissected, and $0.1 \mathrm{~m} l$ of $\mathrm{T}$ cell suspension was injected via the mesenteric vein with a 30 -gauge needle. The dissected abdominal wall was sutured and the skin over the site was closed with Aron alpha A "Sankyo" (Sankyo Co., Ltd., Tokyo). Two weeks 
Table 1. Surface phenotype of $\mathrm{T}$ cell lines

\begin{tabular}{ccc}
\hline & \multicolumn{2}{c}{$\%$ positive cells $^{\mathrm{a}}$} \\
\hline & Anti-TAP line & Anti-SV line \\
\hline Thy1.2 & 98.9 & 99.2 \\
Lyt1.2 & 98.4 & 99.1 \\
L3T4 & 99.9 & 97.7 \\
Lyt2 & 1.4 & 1.5 \\
\hline
\end{tabular}

a) Based on flow cytometry.

later, mice were killed under chloroform anesthesia. The liver, spleen, and several lymph nodes were fixed in $10 \%$ phosphatebuffered formalin. Four- $\mu \mathrm{m}$ paraffin sections were made from the organ and stained with hematoxylin and eosin (HE) and Ziehl Neelsen's method $(\mathbb{Z N})$. Liver sections were made from the left and caudate lobes and the number of hepatic granulomas in 40 microscopic fields at $\times 200$ magnification was counted. The number of granulomas more than 20 per 40 fields was considered to be positive. This criterion for positivity was based on the mean number plus three standard deviations of granulomas of the 29 control mice (injected both anti-SV $\mathrm{T}$ cells and $\mathrm{BCG}$, or $\mathrm{BCG}$ only).

\section{RESULTS}

$\mathrm{T}$ cell lines were established almost according to the method described by Kimoto and Fathman [12]. For antituberculous antigen-specific $T$ cells, single-cell suspensions were prepared from the popliteal lymph nodes of nu/ + mice 14 days after immunization. Lymphocytes were washed twice in 5\% FCS-CM and resuspended in $10 \%$ FCS-CM at a final concentration $2.5 \times 10^{6} / \mathrm{m} l$. Two $\mathrm{m} l$ of this suspension was cultured in a 24-well plastic plate (Costar, \#3424) for 4 days in the presence of 25 $\mu \mathrm{g} / \mathrm{ml} \mathrm{TAP}$, at $37^{\circ} \mathrm{C}$ in $5 \% \mathrm{CO}_{2}$ in air. Cultures were then harvested and blast cells were separated by Ficoll-Paque (Pharmacia
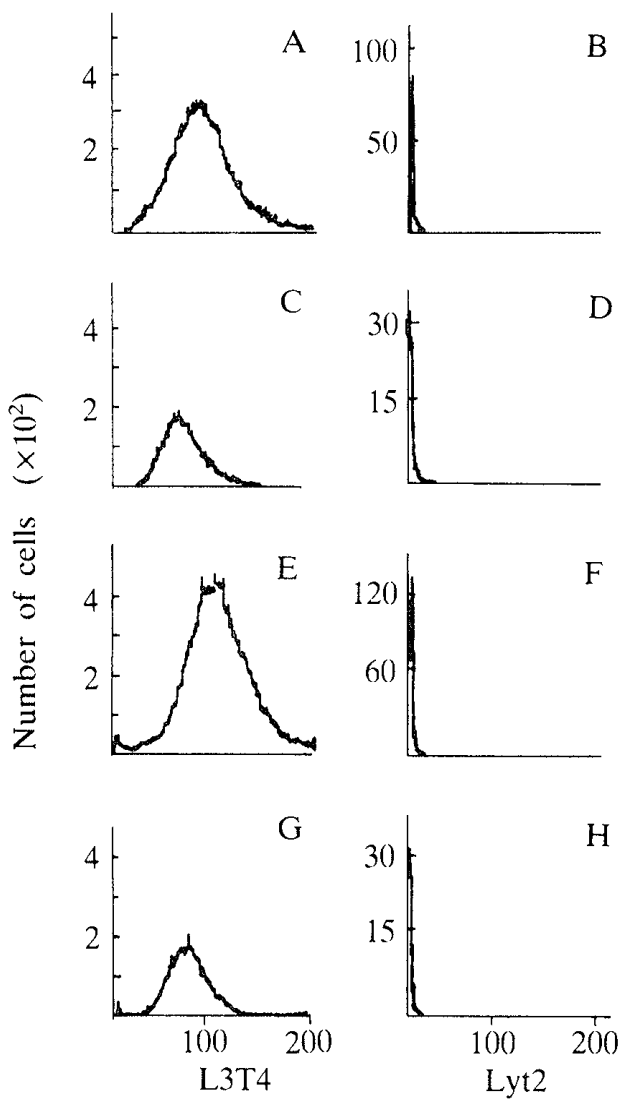

Fluorescence intensity

Fig. 1. Surface phenotype of anti-TAP (A, B, C, D) and anti-SV $(\mathrm{E}, \mathrm{F}, \mathrm{G}, \mathrm{H}) \mathrm{T}$ cell lines at the 3rd $(\mathrm{A}$, B, E, F) and 10th (C, D, G, H) cycle of culture. Cells were stained with L3T4 Mab (A, C, E, G) or Lyt2 $\mathrm{Mab}(\mathrm{B}, \mathrm{D}, \mathrm{F}, \mathrm{H})$ and FITC-conjugated secondary antibody or avidin-FITC and were then analyzed by flow cytometry.

Uppsala, Sweden) at $800 \mathrm{~g}$ for $15 \mathrm{~min}$ at room temperature. The cells at the interface were isolated, washed once in 5\% FCS-CM, resuspended at a final concentration $5 \times 10^{5}$ \% $\mathrm{m} l$ in $10 \%$ FCS-CM containing $5 \times 10^{6}$ APC but without antigen, and cultured for 10 days. After this resting culture, cells were harvested and $5 \times 10^{5}$ viable cells were restimulated with $25 \mu \mathrm{g} / \mathrm{m} l$ TAP and $5 \times 10^{6}$ APC. TAP-reactive T cells were maintained by repeating this cycle: 10 -day resting culture followed by 4-day antigen restimulation culture, for a long period of time ( $>8 \mathrm{mo}$.). At 3 to 10 cycles, $T$ cells after stimulationculture were expanded with $20 \%$ TCGF and used for, experiments. SV-reactive T cell line 
Table 2. Antigen-specific proliferative response of $\mathrm{T}$ cell lines ${ }^{a)}$

\begin{tabular}{|c|c|c|c|}
\hline \multirow{2}{*}{ Antigen } & \multirow{2}{*}{$\begin{array}{l}\text { TCGF } \\
(20 \%)\end{array}$} & \multicolumn{2}{|c|}{${ }^{3} \mathrm{H}-\mathrm{TdR}$ incorporation ${ }^{\mathrm{b})}$. (cpm) } \\
\hline & & Anti-TAP line & Anti-SV line \\
\hline TAP & No & $35607 \pm 9244$ & NT \\
\hline $\mathrm{BCG}$ & No & $23859 \pm 188$ & NT \\
\hline PPD & No & $10339 \pm 4023$ & $1090 \pm 447$ \\
\hline UV-SV & No & $106 \pm 60$ & $39479 \pm 7598$ \\
\hline OVA & No & $223 \pm \quad 8$ & $300 \pm 134$ \\
\hline No & No & $201 \pm 76$ & $502 \pm 394$ \\
\hline No & Yes & $15024 \pm 334$ & $26128 \pm 359$ \\
\hline
\end{tabular}

a) $10^{4}$ lined $\mathrm{T}$ cells were cultured with $5 \times 10^{5} \mathrm{APC}$ and various antigens (tuberculous antigens) and OVA were used at a dose of $25 \mu \mathrm{g} / \mathrm{m} l$ and UV-SV was used at a final dilution of $1: 100$ for 4 days.

b) Determined at the final $18 \mathrm{hr}$ of 4-day culture.

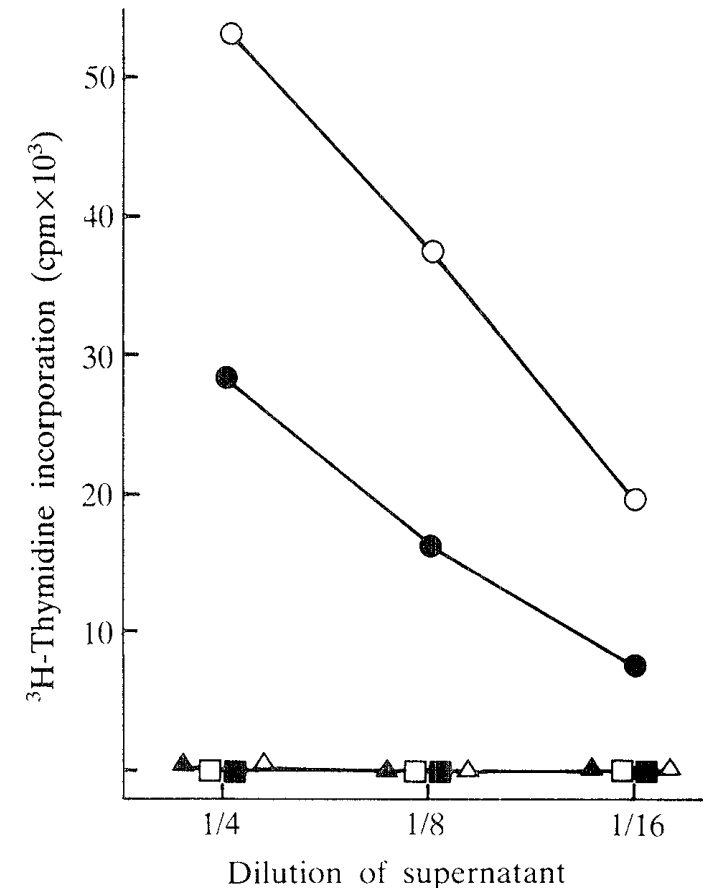

Fig. 3. IL-2 production by $\mathrm{T}$ cell lines. $10^{4}$ anti-TAP $\mathrm{T}$ cells were cultured with $25 \mu \mathrm{g} / \mathrm{m} l \mathrm{TAP}$ and $5 \times 10^{5}$ APC ( ), APC only ( ), TAP only ( $\square$ ), or no APC nor TAP ( for $24 \mathrm{hr} .10^{4}$ anti-Sendai virus T cells were cultured with $2000 \mathrm{HA} \mathrm{UV-SV}$ and $5 \times 10^{5} \mathrm{APC}$ $(\bigcirc)$ or APC only $(\triangle)$. Serially diluted culture supernatants were assayed with CTLL-2 as described in MATERIALS AND METHODS.

was established by the same way from the mediastinal lymph nodes of BALB/cA nu/+ mice infected with SV 4 weeks earlier, using

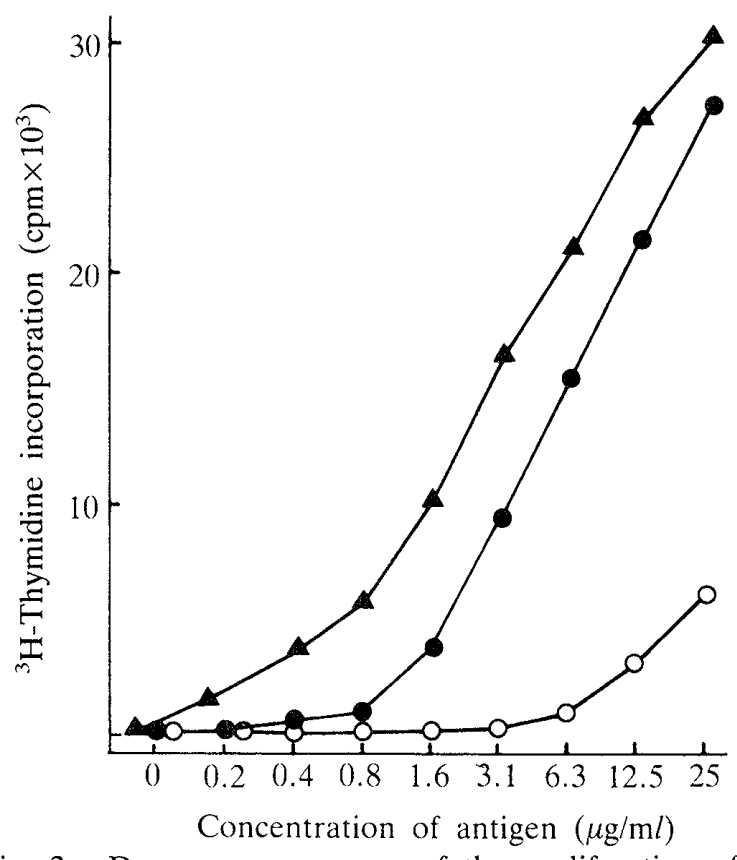

Fig. 2. Dose-response curve of the proliferation of anti-TAP $T$ cell line to tuberculous antigens. $10^{4}$ lined $\mathrm{T}$ cells were cultured with $5 \times 10^{5} \mathrm{APC}$ and with various doses of TAP $(\mathbf{O}), \mathrm{BCG}(\mathbf{\Delta}), \operatorname{PPD}(\bigcirc)$ for 4 days. $\left[{ }^{3} \mathrm{H}\right]-\mathrm{TdR}$ was pulsed for the last $18 \mathrm{hr}$.

UV-SV (2000 HA) as in vitro antigen.

$\mathrm{T}$ cells stained either directly for Thy1.2, or indirectly for Lyt1.2, Lyt 2, or L3T4 were analyzed by flow cytometry. Both lined $\mathrm{T}$ cells were Thy $1.2^{+}$, Lyt $1.2^{+}, \mathrm{L} 3 \mathrm{~T}^{+}$, and Lyt2 ${ }^{-}$surface phenotypes (Table 1 ); flow cytometry analysis was repeated several times during the 3 rd to 10 th cycle, and there was no change their surface phenotypes (Fig. 1).

Next, the uptake of $\left[{ }^{3} \mathrm{H}\right]-\mathrm{TdR}$ by the lined $\mathrm{T}$ cells after stimulation with TAP, heatkilled defatted BCG, PPD, UV-SV, and OVA were investigated. The anti-TAP $\mathrm{T}$ cell line responded to the above tuberculous antigens, but not to UV-SV and OVA. The anti-SV T cell line responded to UV-SV, but not to PPD and OVA (Table 2). Next, we examined the response of anti-TAP $\mathrm{T}$ cell line to varying doses of tuberculous antigens. The anti-TAP $\mathrm{T}$ cell line responded dose-dependently, reacting strongly to TAP and BCG and weakly to PPD (Fig. 2).

As shown in Figs. 3 and 4, the anti-TAP T 


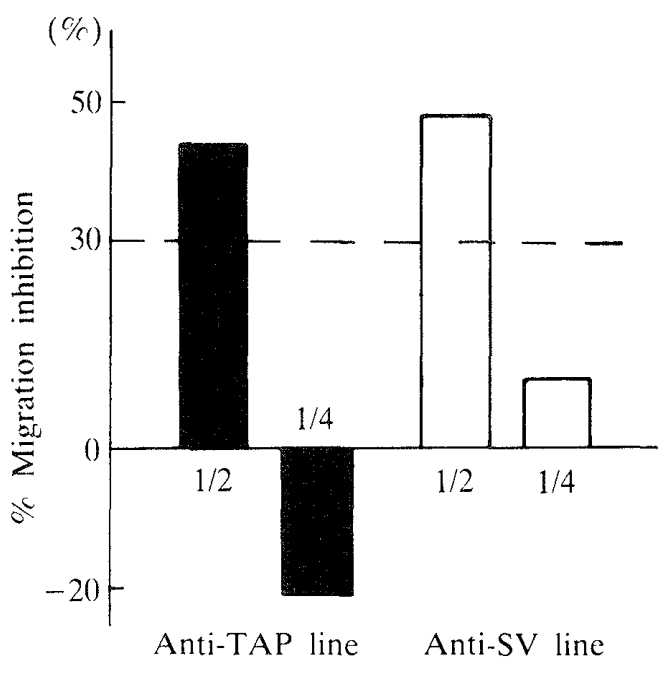

Dilution of supernatant

Fig. 4. MIF production by $\mathrm{T}$ cell lines. $10^{6}$ lined $\mathrm{T}$ cells were cultured with $5 \times 10^{6}$ APC with or without $25 \mu \mathrm{g} / \mathrm{m} l \mathrm{TAP}$ (closed bar) for anti-TAP line, or with or without $2000 \mathrm{HA}$ UV-SV (open bar) for antiSendai virus $\mathrm{T}$ cell line for $24 \mathrm{hr}$. Diluted culture supernatants were assayed by the capillary tube method as described in MATERIALS AND METHODS. cell line was able to produce IL-2 and MIF after antigenic stimulation. The anti-SV T cell line also produced both lymphokines after stimulation with UV-SV.

As shown in Table 3, peak footpad swelling was observed at $24 \mathrm{hr}$ after injection by the local transfer method. Anti-SV T cell line was also able to transfer the delayed footpad response when UV-SV was injected locally with the $T$ cells.

Five $\mathrm{nu} / \mathrm{nu}$ mice were infected via the tail vein with $B C G$, and $24 \mathrm{hr}$ later, $5 \times 10^{5}$ lined $\mathrm{T}$ cells were transferred via the same route, the tail vein, and hepatic granulomas were counted 2 weeks after the transfer (Table 4). Thirty granulomas in average were detected in mice which had received anti-TAP T cells and three in five mice were positive (for the criterion see MATERIALS AND METHODS). Since not all mice given

Table 3. Footpad response by a local passive transfer of $\mathrm{T}$ cell lines

\begin{tabular}{cccccc}
\hline $\begin{array}{c}\text { T cella) } \\
\text { line }\end{array}$ & Antigen $^{\text {b) }}$ No. & \multicolumn{3}{c}{ Footpad swelling } & $(1 / 10 \mathrm{~mm})$ \\
mice & 3hr & $24 \mathrm{hr}$ & $72 \mathrm{hr}$ \\
\hline $\begin{array}{c}\text { Anti-TAP } \\
\text { Yes }\end{array}$ & BCG & & & & \\
Yes & Yes & 5 & $4.3 \pm 1.6$ & $10.1 \pm 3.5^{* *}$ & $3.0 \pm 1.9$ \\
No & Yes & 5 & $1.2 \pm 0.6$ & $0.4 \pm 0.5$ & $0.6 \pm 0.8$ \\
Anti-SV & UV-SV & & & & \\
Yes & Yes & 5 & NT & $4.9 \pm 0.7^{* *}$ & NT \\
Yes & No & 5 & NT & $0.0 \pm 0.0$ & NT \\
No & Yes & 2 & NT & $0.3 \pm 0.4$ & NT \\
\hline
\end{tabular}

a) $5 \times 10^{5} /$ mouse

b) Dose: BCG $20 \mu \mathrm{g} /$ mouse, UV-SV $2000 \mathrm{HA} /$ mouse

** $\mathrm{p}<0.01$

Table 4. Granuloma formation after transfer of $\mathrm{T}$ cell lines via the tail vein

\begin{tabular}{ccccc}
\hline T cell line & $\begin{array}{c}\text { Number } \\
\text { of mice }\end{array}$ & Positive & & \\
& b) $/$ tested & Number of hepatic granulomas \\
\hline Anti-TAP & 5 & $3 / 5$ & $29.0 \pm 21.4^{\text {c) }}(8,13,20,51,53)$ \\
Anti-SV & 5 & $0 / 5$ & $0.2 \pm 0.5$ & $(0,0,0,0,1)$ \\
No cell & 3 & $0 / 3$ & $0.0 \pm 0.0$ & $(0,0,0)$ \\
\hline
\end{tabular}
a) $5 \times 10^{5}$ cells were transferred.
b) $\geqq 20$
c) See Materials and Methods.
d) Individual value in parenthesis. 
Table 5. Granuloma formation after transfer of $\mathrm{T}$ cell line via the portal vein

\begin{tabular}{|c|c|c|c|}
\hline $\begin{array}{l}\mathrm{T} \text { cell line } \\
\text { dose }\end{array}$ & $\begin{array}{l}\text { Number } \\
\text { of mice }\end{array}$ & Positive $^{a)} /$ tested & Number of hepatic granulomas \\
\hline \multicolumn{4}{|l|}{ Anti-TAP } \\
\hline $5 \times 10^{5}$ & 4 & $4 / 4$ & $60.5 \pm 23.6^{* *}(33,55,64,90)^{\mathrm{b})}$ \\
\hline $5 \times 10^{4}$ & 5 & $1 / 5$ & $28.2 \pm 39.1 \quad(8,9,11,15,98)$ \\
\hline $5 \times 10^{3}$ & 4 & $1 / 4$ & $(2,2,4,61)$ \\
\hline \multicolumn{4}{|l|}{ Anti-SV } \\
\hline $5 \times 10^{5}$ & 4 & $0 / 4$ & $(3,4,7,16)$ \\
\hline No cell & 3 & $0 / 3$ & $0.0 \pm 0.0$ \\
\hline
\end{tabular}
a) $\geqq 20$
b) Individual value in parenthesis.
** $\mathrm{p}<0.01$

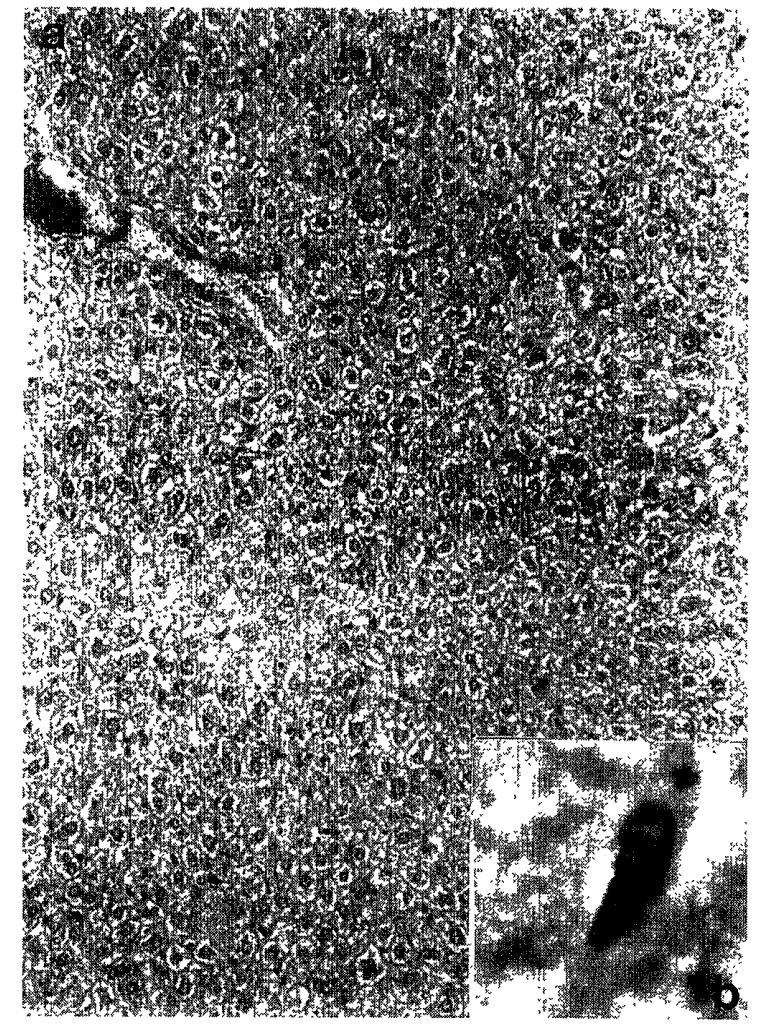

Fig. 5. a) The liver of BCG-infected nu/nu mouse without cell transfer. No marked changes were observed. HE stain $\times 100$. b) Acid-fast bacilli in the Kuppfer cell of control mouse. ZN stain $\times 1000$.

anti-TAP $\mathrm{T}$ cell line showed positive response, we tried transfer of $\mathrm{T}$ cell line via the portal vein, expecting that the injected $\mathrm{T}$ cell line could reach the target organ more effectively. All mice $(5 / 5)$ produced hepatic granulomas after transfer of $5 \times 10^{5}$ antiTAP $T$ cell line, and $1 / 5$ and $1 / 4$ of the mice

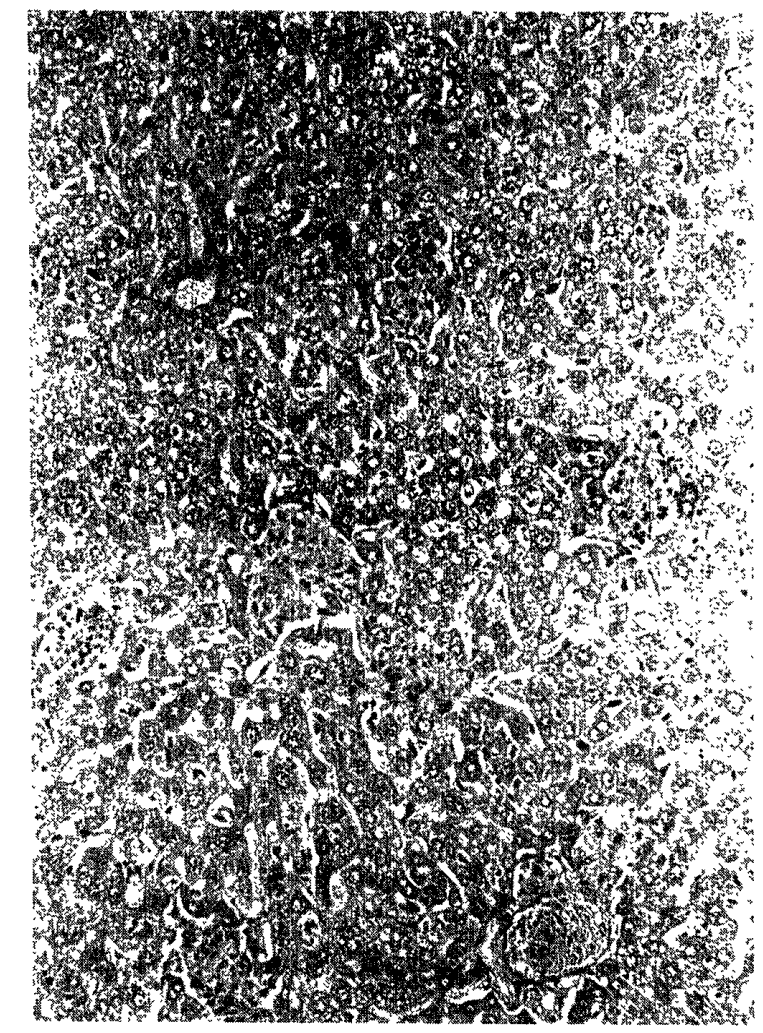

Fig. 6. Granulomas in the liver of BCG-infected $\mathrm{nu} / \mathrm{nu}$ mouse 2 weeks after transfer of anti-TAP T cell line. HE stain $\times 100$.

transferred with anti-TAP T cells at a dose of $5 \times 10^{4}$ and $5 \times 10^{3}$, respectively, also produced granulomas (Table 5). Only a very small number of granulomas were seen in mice which were transferred with anti-SV T cells or in mice without cell transfer.

Histopathologically, hepatic granulomas were seen at intra-lobule and around the 


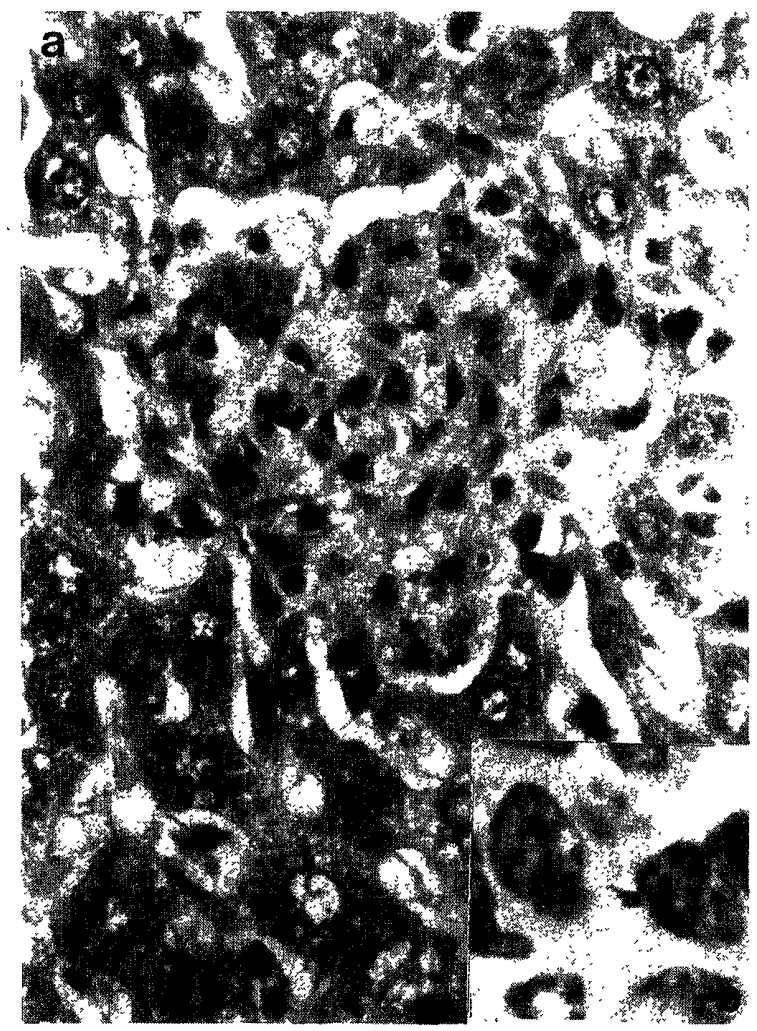

Fig. 7. a) Granulomas (Fig. 6) consisted of macrophages having an elongated nuclei and a wide cytoplasm and were surrounded by a small number of small lymphocytes, and rarely contained polymorphonuclear leukocytes. ZN stain $\times 400$. b) Acid-fast bacilli in the macrophage of hepatic granuloma in BCG-infected nu/nu mouse transferred with anti TAP $T$ cell line. $Z N$ stain $\times 1000$.

interlobular vein (Fig. 6). The size of these granulomas was relatively small and resembled with the granulomas observed after transfer of polyclonal $\mathrm{T}$ cells. Hepatic granulomas consisting of macrophages having an elongated nuclei and a wide cytoplasm were surrounded by a small number of small lymphocytes. Polymorphonuclear leukocytes were seen rarely (Fig. 7a). A small number of acid-fast bacilli were scattered among the granulomas (Fig. 7b). In control mice, very small numbers of granulomas were seen (Fig. 5a), but the infectious foci without inflammatory reactions were frequently observed (Fig. 5b). In the spleen, granulomas were observed at the marginal zone of the splenic follicles and also at the splenic cord of mice which developed hepa-

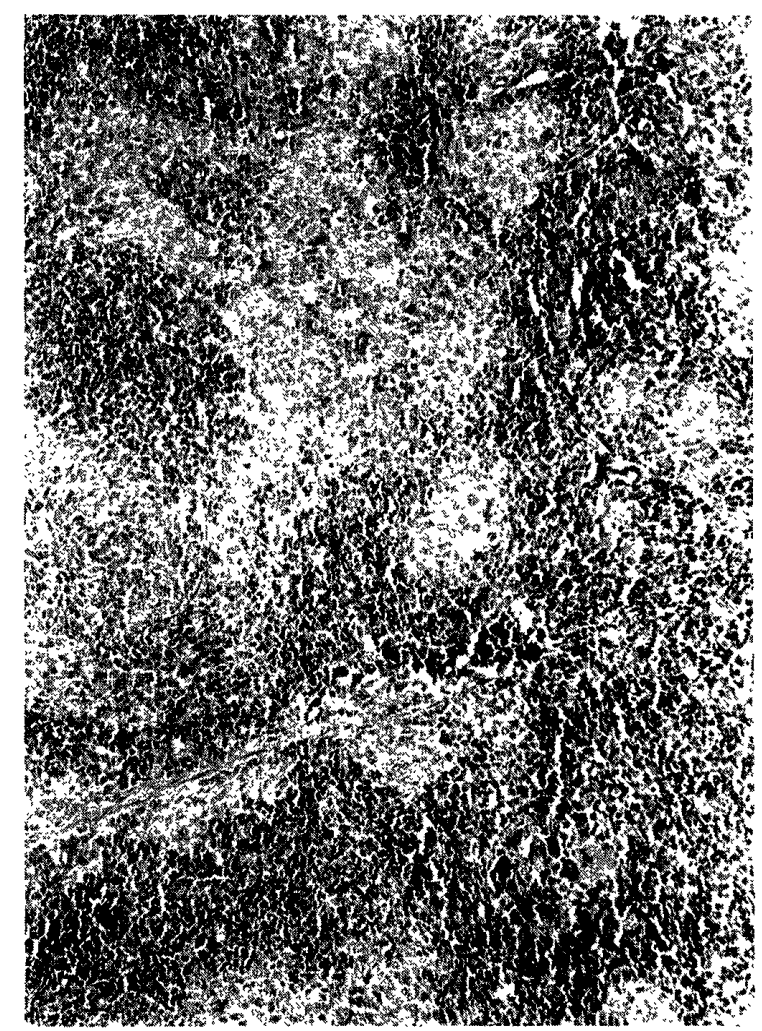

Fig. 8. Granulomas in the splenic white pulps and cords of recipients of anti-TAP $\mathrm{T}$ cell line. HE stain $\times 100$.

tic granulomas (Fig. 8). A small number of acid-fast bacilli were seen in the splenic granulomas. Small numbers of tiny granulomas were constantly seen at the paracortical area of the portal lymph nodes and only rarely in the mesenteric lymphnodes of recipients which developed hepatic granulomas. No marked chages were noticed in the other lymph nodes. Granulomas were not detected in the lungs of any of the mice.

\section{DISCUSSION}

Recent advances in in vitro culture technique, particularly by the use of IL-2, have made possible long-term-culture of homogenous $T$ cells with defined specificities. However, the long-term-cultured T cell lines, which were dependent upon exogenous IL-2, died rapidly when transferred in vivo [5], unless continuous supplementation with IL-2 was made. Thus, these transferred 
cells were functionally limited in vivo without frequent administration of exogenous IL-2 [6]. To overcome the problems of rapid donor $\mathrm{T}$ cell death in vivo, we have developed antigen-driven long-term-cultured $\mathrm{T}$ cell line without employing IL-2 except at the final expansion stage. A long-termcultured $\mathrm{T}$ cell line showing reactivity to tuberculous antigens and homogeneity in regard to the surface markers was obtained. This $\mathrm{T}$ cell line was considered to belong to a subset of $T$ cells with regard to the delayed-type hypersensitivity $\left(\mathrm{T}_{\mathrm{DTH}}\right)$, because it had the surface marker L3T4 and exhibited IL-2 and MIF production in vitro and delayed footpad reaction in vivo, provided tuberculous antigen was applied. Since these lined $\mathrm{T}$ cells exhibited the in vivo activity, it was confirmed that $\mathrm{T}_{\mathrm{DTH}}$ subset was responsible for the infectious granuloma formation. However, our $\mathrm{T}$ cell line was not cloned, so there still remained the possibility of requirement of a $\mathrm{T}$ cell- $\mathrm{T}$ cell interaction in the mechanism of the granuloma formation.

Cultured $\mathrm{T}$ cell lines or clones active in DTH and antibacterial resistance against some bacterial species have been studied in several laboratories [11, 13-17]. In cases in which in vivo activity of $\mathrm{T}$ cell lines or clones was successfully observed, $\mathrm{T}$ cells and bacteria or their antigens were usually transferred into the same site $[11,15-17]$. In fact, our $\mathrm{T}$ cell line could also transfer $\mathrm{DTH}$ adoptively, when both $\mathrm{T}$ cells and BCG were introduced simultaneously into the mouse footpad. When the $T$ cells were transferred systemically into BCG-infected nu/nu mice via the tail vein, hepatic granulomas developed but the rate of production was not high. We thought that insufficient numbers of $T$ cells arrived to the liver since there was a report [7] that a large proportion of i.v.-injected cloned $T$ cells deposited to the lung and only a portion to the liver. Accordingly, we tried to inject lined $\mathrm{T}$ cells via the portal vein, because the target organ in our experimental system was the liver. As shown in Tables 4 and 5, the granuloma formation after transfer of lined $\mathrm{T}$ cells via the portal vein seemed to be better than that via the tail vein.

It has been reported that the long-termcultured $\mathrm{T}$ cell lines revealed an abnormal recirculation or homing pattern $[2,7,8]$. From the observation of tissue section of the present recipient mice, however, we found that granulomas were produced in the splenic white pulps of mice which developed the hepatic granulomas (Fig. 8). This relationship was also observed in mice transferred with a small dose of $\mathrm{T}$ cells. These observations seem to indicate that at least some of injected cultured $\mathrm{T}$ cells did migrate out from the blood vessels and homed to lymphoid tissues.

The experimental system using the in vivo activity of a long-term-cultured $\mathrm{T}$ cell line may facilitate an investigation on the cellular interaction presumably operating in the granuloma formation. Furthermore, the cloning of a $\mathrm{T}$ cell line might enable investigation of the epitopes relating to the granuloma formation and further, the antimycobacterial immunity.

ACKNOwLEDGEMENTS. The authors wish to thank Dr. S. Kyuwa of the Institute of Medical Science, University of Tokyo for assisting our use of the flow cytometry system and we also thank Mr. K. Takamoto, Mr. Y. Kamimura, and Mr. M. Kimura for their assistance in the animal experiments. This study was supported in part by a Grant-in-Aid for Scientific Research from the Ministry of Education, Science and Culture, Japan, and in part by a grant from the Ministry of Health and Welfare (Japan-US Cooperative Medical Science Program, Tuberculosis Panel).

REFERENCES

1. Azuma, I., Kimura, H., Niinaka, T., Aoki, T., and Yamamura, Y. 1968. Chemical and immunological studies on mycobacterial polysaccharides. I. Purification and properties polysaccharides from human tubercle bacilli. J. Bacteriol. 95: 
263-271.

2. Bookman, M. A., Groves, E. S., and Matis, L. A. 1986. Expression of MEL-14 antigen is not an absolute requirement for dissemination to lymph nodes after adoptive transfer of murine T lymphocyte clones. J. Immunol. 137: 2107-2114.

3. Boros, D. L. 1978. Granulomatous inflammations. Prog. Allergy 24: 183-267.

4. Chaparas, S. D. 1982. The immunology of mycobacterial infections. pp. 139-197. In: CRC critical reviews in microbiology.

5. Cheever, M. A., Greenberg, P. D., Irle, C., Thompson, J. A., Urdil, D. L., Mochizuki, D. Y., Henney, C. S., and Gillis, S. 1984. Interleukin 2 administered in vivo induces the growth of cultured $\mathrm{T}$ cells in vivo. $J$. Immunol. 132: 2259-2265.

6. Cheever, M. A., Thompson, J. A., Kern, D. E., and Greenberg, P. D. 1984. Interleukin-2 administered in vivo induces the growth and augments the function of cultured $\mathrm{T}$ cells in vivo. J. Biol. Response Modifiers 3: 462-467.

7. Dailey, M. O., Fathman, C. G., Butcher, E. C., Pillemer, E., and Weissman, I. 1982. Abnormal migration of $\mathrm{T}$ lymphocyte clones. J. Immunol. 128: 2134-2136.

8. Dailey, M. O., Gallatin, W. M., and Weissman, I. L. 1985. The in vivo behavior of T cell clones: Altered migration due to loss of the lymphocyte surface homing receptor. J. Mol. Cell. Immunol. 2: $27-36$

9. Ertl. H. C. 1981. Adoptive transfer of delayedtype hypersensitivity to Sendai virus. II. Different modes of antigen presentation determine K,Dregion or $\mathrm{I}$-region restriction of $\mathrm{T}$ cells mediating delayed-type hypersensitivity to Sendai virus. Cell. Immunol. 63: 188-192.

10. Gillis, S., Ferm, M. M., Ou, W., and Smith, K. A. 1978. T cell growth factor: Parameters of production and a quantitative microassay for activity. J. Immunol. 120: 2027-2032.

11. Hussein, S., Curtis, J., Akuffo, H., and Turk, J. L., 1987. Dissociation between delayed-type hypersensitivity and resistance to pathogenic mycobacteria demonstrated by T-cell clone. In- fect. Immun. 55: 564-567.

12. Kimoto, M., and Fathman, C. G. 1980. Antigenreactive $\mathrm{T}$ cell clones. I. Transcomplementing hybrid I-A-region gene products function effectively in antigen presentation. J. Exp. Med. 152: 759-769.

13. Kaufmann, S. H. E., and Hahn, H. 1982. Biological functions of $\mathrm{T}$ cell lines with specificity for the intracellular bacterium Listeria monocy. togenes in vitro and in vivo. J. Exp. Med. 155: 1754-1765.

14. kaufmann, S. H. E. 1983. Effective antibacterial protection induced by a Listeria monocytogenesspecific $\mathrm{T}$ cell clone and its lymphokines. Infect. Immun. 39: 1265-1270.

15. Kaufmann, S. H. E. 1984. Biological activities of a murine T-cell clone with reactivity to Mycobacterium leprae. Cell. Immunol. 83: 215-220.

16. Paul, C., Shalala, K., and Warren, R., and Smith, R. 1985. Adoptive transfer of murine host protection to salmonellosis with $\mathrm{T}$-cell growth factordependent, salmonella-specific T-cell lines. Infect. Immun. 48: 40-43.

17. Predrazzini, T., and Louis, J. A. 1986. Functional analysis in vitro and in vivo of Mycobacterium bovis strain BCG-specific $\mathrm{T}$ cell clones. J. Immunol. 136: 1828-1834.

18. Ueda, K., Yamazaki, S., Saegusa, J., and Someya, S. 1978. Progressive and fatal infection with attenuated mycobacterium bovis (BCG) in nude mice. Jpn. J. Exp. Med. 48: 533-543.

19. Ueda, K., Yamazaki, S. Yamamoto, S., and Someya, S. 1982. Spleen cell transfer induces T cell-dependent granulomas in tuberculous nude mice. J. Reticuloendothel. 31: 467-478.

20. Ueda, K., Yamazaki, S., and Yamamoto, S. 1983. H-2 I region restriction phenomenon in $\mathrm{T}$ cell-dependent granuloma formation to Mycobacterium bovis BCG. J. Reticuloendothel. 34: 475-484.

21. Yamamura, Y., Onoue, K., and Tahara, T. 1969. Purification and the properties of tuberculin active peptide. Z. Immun., Allergie Klin. Immunologie 137: 170-176. 
要 約

結核抗原特異的 T細胞株の樹立㧍よび BCG 感染ヌードマウスに扔ける肝肉芽腫形成能：山本茂貴・岩井 浤・上田雄幹（国立公衆衛生院，衛生獣医学部）——結核菌（青山 B 株）死菌免疫 BALB / c ヘテロ $(\mathrm{nu} /+$ ) マウスの膝窩リンパ節細胞から，抗原刺激一休止培養サイクルを反復する方法で，ツベルクリン活性ペプチド （TAP）反応性 T 細胞 line を樹立した。得られたT 細胞 line は Thy1 $.2^{+}$, Lyt1.2 $2^{+}, \mathrm{L} 3 \mathrm{~T} 4^{+}, \mathrm{Lyt} 2$ で, IL-2 おう よびMIF 産生能を有し，in vivoでの遅延型足蹠反応を示すことから，T T DTH サブセットに属するとみなされた。 結核抗原に特異的に反応する TAP 反応性 T 細胞 line は BCG 感染ヌードマウスに移入後 2 週で肝に肉芽腫を形 成出来たことから，TDTH が肝肉芽腫形成に関与するT細胞サブセットであることが確認された．さらにT 細胞 line を移入されたマウス肝の観察で，肉芽腫を認めたマウスでは脾の白脾髄周囲にも肉芽腫を認めたことから， 少なくとも移入 T 細胞の一部はまず脾に到達して再刺激を受けた後，肝肉芽腫形成に関与することが示唆された． 